\title{
Modulatory activity and chemical profile of a hydroalcoholic extract of Crateva tapia L.
}

\author{
Daniela L. de V. Cabral ${ }^{1}$, Valérium T. N. A. Castro ${ }^{1}$, Henrique Douglas Melo Coutinho ${ }^{2}$, Saulo \\ Relison Tintino ${ }^{2}$, Cícero Diego Almino Menezes ${ }^{2}$, Irwin R. A. Menezes ${ }^{2}$, \\ Ulysses Paulino de Albuquerque ${ }^{3}$ and Elba Lúcia Cavalcanti de Amorim ${ }^{1 *}$
}

${ }^{1}$ Laboratory of Natural Products, Department of Pharmaceutical Sciences, Federal University of Pernambuco, Av. Prof. Arthur de Sá, s/n, Cidade Universitária, CEP 50740-521, Recife-PE, Brazil.

${ }^{2}$ Laboratory of Medicinal Chemistry and Pharmacology (LFQM), Department of Biological Chemistry, Regional University of Cariri, Cel. Antonio Luis 1161, Crato-CE, Brazil.

${ }^{3}$ Laboratory of Aplied Ethnobotany, Biology Department, Botany Area, Federal Rural University of Pernambuco, Av. Dom Manoel de Medeiros s/n, Dois Irmãos. CEP: 52171-900. Recife-PE, Brazil.

Received 30 July, 2014; Accepted 12 January, 2015

\begin{abstract}
The scientific community is constantly searching for innovative substances that have antimicrobial potential and the ability to reduce or eliminate bacterial antibiotic resistance to specific drugs. This ability is known as the modulatory activity of antibiotics. Crateva tapia L., popularly known as "trapiá," is a plant belonging to the Capparaceae family and is used in northeastern Brazil as a tonic, antidiarrheal, antipyretic, hypotensive and muscle relaxant. We investigated the phytochemical profile and the antibiotic and modulating activity of a hydroalcoholic crude extract (CECT) against multi-drug resistant strains of Escherichia coli, Staphylococcus aureus and Pseudomonas aeruginosa, all of which were isolated from surgical wounds. A phytochemical assay detected the presence of phenols and alkaloids. The minimum inhibitory concentration (MIC) of CECT against all of the strains used was $\geq$ $1024 \mu \mathrm{g} / \mathrm{mL}$. The extract synergistically modulated the antibiotic resistance to Amikacin of $S$. aureus, reducing the MIC from 312.5 to $39.06 \mu \mathrm{g} / \mathrm{mL}$ (an $87.5 \%$ reduction). The same occurred in the case of gentamicin against $S$. aureus and $P$. aeruginosa. In both cases, the MIC was reduced from 312.5 to 78.12 $\mu \mathrm{g} / \mathrm{mL}$, a reduction of $75 \%$. Although the antimicrobial activity of $C$. tapia extract is clinically irrelevant, it showed significant modulatory activity, justifying further fractionation and tests with other strains and antibiotics.
\end{abstract}

Key words: Antimicrobial activity, Escherichia coli, Pseudomonas aeruginosa, Staphylococcus aureus, amikacin, gentamicin, neomycin.

\section{INTRODUCTION}

The property of reducing or eliminating bacterial antibiotic resistance to specific drugs is known as the modulatory activity of antibiotics (Gunics et al., 2002). Some studies have reported substances or plant extracts with modulatory antibiotic activity against various microorganisms
(Palaniappan and Holley, 2010; Hemaiswarya and Doble, 2009; Yap et al., 2013). It is even possible that a substance that has no antibiotic activity when used alone can present a potent modulatory activity when associated with antibiotics and antifungals (Morais-Braga et al., 
2013).

Proof of Darwinian natural selection can be observed in the increasing emergence of bacteria that have become resistant to multi-drug antibiotics and that are categorized as having "extensive drug-resistance" (Park et al., 2011). Upon acquiring resistance, pathogenic, saprophytic and commensal bacteria can potentially result in pathogens that can cause physiological damage (Razera et al., 2009). This has raised great concern in the scientific community, resulting in the constant search for innovative substances.

If the mutations responsible for resistance were to occur individually, this problem would not be so severe. However, many transposons and plasmids confer resistance on a variety of classes of antibiotics (Livermore, 2007). Such selection, in most instances, occurs in an artificial and accelerated manner through the indiscriminate use of antibiotic substances, causing serious problems with regard to antibiotic therapy.

Various species of bacteria now fall within the category of "extensive drug-resistance", as observed in the cases of Escherichia coli, Staphylococcus aureus and Pseudomonas aeruginosa. E. coli, despite being part of the normal flora of the gastrointestinal tract, has multidrug resistant strains that have caused infections in other locations, such as the urinary tract, lungs, heart valve, and blood stream (Wright and Perinpanayagam, 1987; Caso et al., 2008). This microorganism has been responsible for serious nosocomial and community outbreaks in different parts of the world and is considered the sixth most dangerous pathogen to human health (Pacheco et al., 2013). In regard to hospital contaminations, $P$. aeruginosa is one of the main bacteria responsible for multi-drug resistant infections. Isolated versions of these strains of $P$. aeruginosa can be obtained from various sites of infection, such as hair follicles, nails, lungs, the urinary tract and surgical wounds (Kerr and Snelling, 2009). Methicillin-Resistant Staphylococcus aureus (MRSA) strains also play a major role in hospital outbreaks. In more than half of Latin America, MRSA has been identified in more than $50 \%$ of all clinical isolates of $S$. aureus (Guzmán-Blanco et al., 2009). Data from 2001 showed a surprising increase, from 0.7 to $14.8 \%$, in the prevalence of MRSA in clinical isolates from patients in the British Isles (Livermore et al., 2003).

Ethnobotany and ethnopharmacology have emerged as very important tools in the study of the customs and usages of medicinal plants in traditional communities. These tools have identified plants with promising antimicrobial activity in specific and even global ecosystems (Almeida et al., 2012; Mbosso et al., 2010; Canales et al., 2005).
In general, common popular knowledge is corroborated by biological assays (Leitão et al., 2013), often leading researchers in the fields of phytochemistry and pharmacology to adopt a directly ethnopharmacological approach. This is not only the quickest but also the least costly method for selection of species with biological activity (Albuquerque and Hanazaki, 2006).

The present study, therefore, aimed to study the antimicrobial activity of Crateva tapia L., a species used in popular medicine in Northeastern Brazil, selected on the basis of ethnopharmacological information. C. tapia L. belongs to the Capparaceae family and is found in a variety of environments, such as the Atlantic rain forest and Pantanal and Caatinga of the Brazilian Northeast. The plant is consumed as food by monkeys, fish and birds and humans have not only utilized it for timber but also for its medicinal properties (Lorenzi, 1998). The stem bark of this tree has traditionally been employed for a variety of purposes: as a tonic, an anti-diarrheal, an antipyretic (Araújo, 2008), a hypotensive and a muscle relaxant (Albuquerque et al., 2007), and in the treatment of urinary disorders and inflammation (Patil et al., 2010). One of such ethnobotanical study of plants with purported anti-inflammatory activity was carried out in the interior of the state of Pernambuco, Brazil.

In this study, C. tapia was also considered appropriate for treating kidney pain and sore throats (Ferreira Júnior et al., 2011). Inflammatory processes may result from tissue damage caused by bacteria (Guyton and Hall, 2006) and a species popularly known as an anti-inflammatory agent may thus in fact be producing this effect because it possesses antimicrobial properties.

With a view to furthering knowledge of this species, the present study determined the phytochemical profile of a hydroalcoholic extract and evaluated the antimicrobial and modulatory activity of the hydroalcoholic extract of $C$. tapia stem bark against multi-resistant strains of $E$. coli, $S$. aureus and $P$. aeruginosa.

\section{MATERIALS AND METHODS}

\section{Drugs}

Gentamicin, Amikacin, and Neomycin were purchased from SIGMA Co. (St. Louis, MO). The solutions of antibiotics were prepared in accordance with the recommendations of the Clinical and Laboratory Standards Institute (NCCLS, 2008).

\section{Plant material}

Cr. tapia L. bark was collected from a remnant of deciduous thorny vegetation (Caatinga) in the State of Pernambuco, Northeastern Brazil, in April and May of 2011 during the beginning of the rainy season. The species was identified by Dra. Lucilene Lima dos 
Table 1. Antibiogram of the strains used in the microbiological assays.

\begin{tabular}{|c|c|c|}
\hline Bacteria & Origin & Resistance \\
\hline Escherichia coli 27 & Surgical Wound & $\begin{array}{l}\text { Ast, Ax, Ami, Amox, Ca, Cfc, Cf, Caz, Cip, Chlo, Im, Kan, } \\
\text { Szt, Tet, Tob }\end{array}$ \\
\hline $\begin{array}{l}\text { Staphylococcus aureus } \\
358\end{array}$ & Surgical Wound & Oxa, Gen, Tob, Ami, Kan, Neo, Para, But, Sis, Net \\
\hline $\begin{array}{l}\text { Pseudomonas } \\
\text { aeruginosa } 03\end{array}$ & Urine culture & Cpm, Ctz, Im, Cip, Ptz, Lev, Mer, Ami \\
\hline
\end{tabular}

Ast - Aztreonan; Ax - Amoxicillin; Amp - Ampicillin; Ami - Amikacin; Amox - Amoxicillin; Ca - Cefadroxil; Cfc - Cefaclor; Cf Cephalothin; Caz -Ceftazidime, Cip - Ciprofloxacin; Chlo - Chloramphenicol; Im - Imipenem; Kan - Kanamycin; Szt Sulphametrim; Tet - Tetracycline; Tob -Tobramycin; Oxa - Oxacillin; Gen - Gentamicin; Neo - Neomycin; Para Paramomicin - But - Butirosin; Sis - Sisomicin Net - Netilmicin, Cpm - Cefepime, Ctz - ceftazidime, Ptz - Piperacilintazobactam, Lev - levofloxacin; Mer - Meropenen.

Santos and a voucher specimen was deposited in the Prof. Vasconcelos Sobrinho Herbarium at the Universidade Federal Rural de Pernambuco under the number 48,718 . Stem bark from at least three individual samples was collected to cover intra-species variations relating to the quality and quantity of secondary metabolites. The samples were dried at room temperature for 7 to 15 days and then pulverized in a Wiley mill with a standard 20 mesh particle screen.

\section{Microorganism}

The bacterial strains used in this study were $E$. coli (EC27) S. aureus (SA358) and $P$. aeruginosa (PA03). All the strains were clinical isolates with a profile of multi-drug resistance, as shown in Table 1. The strains were maintained in a tilted Brain-Heart Infusion agar (BHI, Difco Laboratories Ltda.) under refrigeration. Before conducting the test, the cells were cultured for $24 \mathrm{~h}$ at $37^{\circ} \mathrm{C}$ in $\mathrm{BHI}$ (BHI, Difco Laboratories Ltda).

\section{Extract preparation}

The extract was obtained by maceration of powdered stem bark of C. tapia L. in ethanol (70\%). Seven successive extractions were carried out at 24-h intervals. The eluent was filtered through filter paper and $100 \mathrm{~mL}$ of fresh solvent was added to the solid residue. The total liquid extract was dried by using a rotary evaporator at temperatures below $40^{\circ} \mathrm{C}$ and under reduced pressure. The extraction product was used to prepare the solutions at $10 \mathrm{mg} / \mathrm{mL}$, dissolved in dimethyl sulfoxide (DMSO) and then diluted with distilled water to a concentration of $1024 \mu \mathrm{g} / \mathrm{mL}$.

\section{Phytochemistry}

Different classes of secondary metabolites were evaluated with regard to their presence/absence in the extract. Tests for phenols, tannins, flavonoids, steroids, triterpenes, alkaloids, coumarins and saponins were carried out using the methodology described by Matos (1997). The assays were based on the formation of color or precipitation after addition of reagents specific to each class of secondary metabolite.

\section{Antimicrobial activity assay}

The method developed by Javadpour et al. (1996) assessed the antibiotic activity of hydroalcoholic extract of C. tapia L. against $E$. coli (EC27), S. aureus (SA358) and $P$. aeruginosa (PA03). Bacterial inoculants for each strain were suspended in a $3.8 \% \mathrm{BHI}$ broth and grown in a bacteriological incubator for $24 \mathrm{~h}$ at $37^{\circ} \mathrm{C}$. After growth, each suspension was diluted to $10 \% \mathrm{BHI}$ at a concentration of $1 \mathrm{x}$ $10^{6} \mathrm{CFU} / \mathrm{mL}$ and distributed in 96 -well plates as follows: $100 \mu \mathrm{L}$ of bacterial suspension per $100 \mu \mathrm{L}$ of extract at different concentrations, to a final concentration of $5 \times 10^{5} \mathrm{CFU} / \mathrm{mL}$. The extract solution previously prepared at a concentration of 1024 $\mu \mathrm{g} / \mathrm{mL}$ was used to perform serial dilutions until concentrations in the range of $512-8 \mu \mathrm{g} / \mathrm{mL}$ were obtained. All assays were carried out in triplicate and the plates were incubated in a bacteriological incubator at $35 \pm 2^{\circ} \mathrm{C}$ for $24 \mathrm{~h}$.

\section{Modulatory activity assay}

To assess antibiotic resistance modulatory activity, the minimum inhibitory concentration (MIC) for each antibiotic was determined, as described in the previous section, in the presence and absence of the extract at a sub-inhibitory concentration (MIC/8) (Coutinho et al., 2008). For each clinically isolated strain, three antibiotics were used: Amikacin, Neomycin and Gentamicin, at final concentrations ranging from $2500-1 \mu \mathrm{g} / \mathrm{mL}$. The colorimetric method of adding resazurin was used to evaluate antibacterial activity. After incubation, $25 \mu \mathrm{L}$ of a $0.01 \%$ aqueous resazurin solution was added to each well. In the presence of bacterial growth, resazurin changes color from blue to pink. The minimum inhibitory concentration was determined to be the last dilution where there was no cell growth.

\section{RESULTS}

Phytochemical analysis of crude hydroalcoholic extract of C. tapia (CECT) showed the presence of phenols of the flavone, flavonol and xanthone types. In addition to these, alkaloids were also found. These data are shown in Table 2 , with the presence or absence of each metabolite under analysis indicated by + or -, respectively.

The minimum inhibitory concentration of the CECT against all strains used in this study cannot be determined because there was bacterial growth at all concentrations $\geq 1024 \mu \mathrm{g} / \mathrm{mL}$. The results for antibiotic resistance modulatory activity are presented in Table 3. 
Table 2. Phytochemical analysis of a hydroalcoholic crude extract of stem bark of C. tapia L..

\begin{tabular}{|c|c|c|c|c|c|c|c|c|c|c|c|c|c|c|c|c|c|c|c|}
\hline \multicolumn{20}{|c|}{ Metabolite } \\
\hline Extract & 1 & 2 & 3 & 4 & 5 & 6 & 7 & 8 & 9 & 10 & 11 & 12 & 13 & 14 & 15 & 16 & 17 & 18 & 19 \\
\hline CECT & + & - & - & - & - & + & + & + & - & - & - & - & - & - & - & - & - & + & - \\
\hline
\end{tabular}

The presence $(+)$ or absence $(-)$ of the different metabolites is indicated. 1- Phenols; 2- hydrolyzable tannin; 3- condensed tannin; 4anthocyanins; 5- anthocyanidins; 6- flavones; 7- flavonols; 8 - xanthones; 9- chalcones; 10 - aurones; 11 - flavononols; 12- leukoanthocyanidins; 13- catechins; 14- flavonones; 15- cumarines, 16-free steroids, 17 - pentacyclic triterpenoids, 18- alkaloids; 19- saponins.

Table 3. Modulatory activity of antibiotic activity of a crude extract C. tapia L. against multi-resistant strains (MIC at $\mu \mathrm{g} / \mathrm{mL})$.

\begin{tabular}{lccccccccc}
\hline & \multicolumn{3}{c}{ Escherichia coli 27 } & \multicolumn{2}{c}{ Staphylococcus aureus 358 } & \multicolumn{2}{c}{ Pseudomonas aeruginosa 03 } \\
\cline { 2 - 10 } Antibiotic & Ant. & $\begin{array}{c}\text { Ant. + } \\
\text { CECT }\end{array}$ & $\begin{array}{c}\text { Reduction } \\
\text { (\%) }\end{array}$ & Ant. & $\begin{array}{c}\text { Ant. + } \\
\text { CECT }\end{array}$ & $\begin{array}{c}\text { Reduction } \\
\text { (\%) }\end{array}$ & Ant. & $\begin{array}{c}\text { Ant. + } \\
\text { CECT }\end{array}$ & $\begin{array}{c}\text { Reduction } \\
\text { (\%) }\end{array}$ \\
\hline Amikacin & 78.12 & 78.12 & 0 & 312.5 & 39.06 & 87.5 & 312.5 & 312.5 & 0 \\
Neomycin & 156.25 & 625 & -400 & 156.25 & 156.25 & 0 & 312.5 & 312.5 & 0 \\
Gentamicin & 312.5 & 312.5 & 0 & 312.5 & 78.12 & 75.0 & 312.5 & 78.12 & 75.0 \\
\hline
\end{tabular}

Ant.- Antibiotic, CECT- crude extract of C. tapia.

Of particular interest is the synergistic activity with Amikacin against SA358, in which the MIC decreased from 312.5 to $39.06 \mu \mathrm{g} / \mathrm{mL}$, which represents a reduction of approximately $87.5 \%$ in the concentration needed to inhibit microbial growth. Another important result was obtained for gentamicin against SA358 and PA03. The MIC for both strains decreased from 312.5 to 78.12 $\mu \mathrm{g} / \mathrm{mL}$, a reduction of approximately $75 \%$. It is also worth highlighting the antagonistic activity when the extract was combined with Neomycin and then exposed to EC27, where the MIC increased from 156.25 to $625 \mu \mathrm{g} / \mathrm{mL}$, reducing the power of the antibiotic by $400 \%$ in terms of the concentration required to prevent bacterial proliferation.

\section{DISCUSSION}

No study to date, to our knowledge, has evaluated the antimicrobial activity of a hydroalcoholic extract of $C$. tapia. However, Salvat et al. (2001) tested the methanolic crude extract of the species in question and found an MIC of $500 \mu \mathrm{g} / \mathrm{mL}$ against $P$. aeruginosa ATCC strains, considering active extracts to be those that obtained an MIC of less than or equal to $500 \mu \mathrm{g} / \mathrm{mL}$. The present study, using a hydroalcoholic extract, did not find this level of activity. This difference in activity may be explained by the fact that the samples in the two studies were collected from different regions. Although both studies were conducted on the same continent, GobboNeto and Lopes (2007) have reported that the quantity and quality of secondary metabolites can be influenced by the climate, altitude, soil and radiation levels. Even within the same collection area, slight differences, such as the habitat where each specimen is collected, can produce statistically significant differences in results. This has been demonstrated by Araújo et al. (2012) in a model for the species Spondias tuberosa that investigated the tannin levels and the antioxidant activity of sequestrated free radicals. It should also be pointed out that Salvat et al. (2001) did not use clinically isolated multi-resistant strains but rather standard sensitivity ATCC strains, which normally exhibit a higher degree of susceptibility to substances with antibiotic potential.

The evaluation of phytochemical compounds conducted by this study did not find a wide variety of secondary compound classes, as observed in previous studies by the same team. These compounds can be classified broadly into phenols and alkaloids. Patil et al. (2010), in a study of the pharmacognosy of C. Tapia leaves, also identified the presence of phenols and alkaloids and other metabolics such as steroids and glycosides. Phenols are substances commonly associated with antimicrobial activity in various plant species, as observed by Machado et al. (2003), who found polyphenols isolated from the extract of Punica granatum to be responsible for activity against methicillin-resistant $S$. aureus strains. Although the present study detected the 
presence of phenols in the sample tested, the antimicrobial activity of the crude hydroalcoholic extract of C. tapia against the three strains tested (E. coli; S. aureus; $P$. aeruginosa) was not of clinical importance, because the MIC was $\geq 1024 \mu \mathrm{g} / \mathrm{mL}$, a concentration considered impractical for therapeutic applications.

Although the extract did not seem to exhibit clinically significant activity against the tested microorganisms, antibiotic modulatory activity was observed with some combinations. This concurs with the findings of MoraisBraga et al. (2013), who tested the crude hydroalcoholic extract of Lygodium venustum against these same strains. In that particular case, the extract tested was considered inactive with an MIC $\geq 1024 \mu \mathrm{g} / \mathrm{mL}$. However, when tested in combination with antibiotic aminoglycosides, modulatory action exhibited a pronounced decrease of $99 \%$ in MIC. An evaluation of the antimicrobial activity of a methanol and hexane extract of Ocimum gratissimum, a plant species common in the semi-arid regions of Northeastern Brazil, against $S$. aureus did not reveal clinically significant activity (MIC $\geq 1024 \mu \mathrm{g} / \mathrm{mL}$ ). However, in combination with Neomycin, there was significant synergism, decreasing the MIC of the antibiotic from 317 to $2.2 \mu \mathrm{g} / \mathrm{mL}$ (Matias et al., 2011). These findings reinforce the idea that one should never overlook the potential modulatory effect of an extract based solely upon its antimicrobial activity, as it has been demonstrated that, even when an extract is considered inactive against certain strains, it may present important synergism when used in combination with antibiotics frequently used in medical practice.

The combination with the antibiotic Neomycin against EC27 exhibited antagonistic activity of $400 \%$. Antibiotic resistance can occur by way of three main mechanisms of action: modification of the binding site with a reduction in drug-receptor interaction, modification or destruction of the antibiotic molecule by enzyme action, and efflux of the antibiotic by way of preventing the ingress or expulsion of the same molecules which have penetrated the microorganism. A plant extract or isolated substance, natural or synthetic, may interfere with any of these bacterial resistance mechanisms, producing an antagonistic modulating effect (Wagner and Ulrich-Merzenich, 2009).

The phenols found in the extract investigated by the present study were classified as flavones and flavonols, which may explain their modulatory activity, since, according to Cowan (1999), these compounds are able to create a complex in the bacterial cell wall, causing the expression of membrane receptors that alter the profile of resistance to a particular antibiotic. Another mechanism of action for the modulatory activity of antibiotics through polyphenols has been described by Samoilova et al. (2013) using strains of E. coli. The researchers concluded that these compounds may reduce the bactericidal action of Ciprofloxacin and Ampicillin and increase bacterial sensitivity to Kanamycin by reduced or increased oxidative stress induced by the antibiotic. This shows that the crude extract may have synergistic or antagonistic effects depending on the strain and associated antibiotic being tested.

Alkaloids are widely known for their activity in the central nervous system but this class of secondary metabolites is also acquiring importance in microbiology. Xing et al. (2012) evaluated the activity of the alkaloid harmaline against clinically isolated strains of $\mathrm{S}$. aureus in combination with the antibiotic chlorhexidine. Their study found that harmaline is a relatively weak substance when confronted with strains tested in cells in suspension as well as in biofilms. However, when combined with chlorhexidine, it showed a significant synergistic effect against almost all clinical isolates tested. Another alkaloid whose antimicrobial activity has been assessed is Berberine, a derivative of isoquinoline. Berberine in fact shows activity both when used alone and in combination with chlorhexidine against a mixture of oral biofilm forming micro-organisms (Xie et al., 2012).

As far as we are aware, no study of the modulatory antibiotic activity of this plant species or even of the Capparaceae family can be found in the literature available to date.

It is worth highlighting one of the most useful results presented in this study: C. tapia crude extract in combination with the antibiotic Amikacin against $S$. aureus produced an MIC reduction of $87 \%$. This plant species is thus a good candidate for future studies, such as extract fractionation. The same can be said of other extract types and plant parts of $C$. tapia.

\section{Conclusion}

The present study has extended phytochemical knowledge of $C$. tapia, and identified the presence of phenols and alkaloids in the hydroalcoholic extract of its stem bark. It has further demonstrated the modulatory antibiotic activity of this species, although it does not exhibit this activity when used alone. These findings also reveal the need to expand studies aiming to combine plant extracts with commercial antibiotics to combat microbial multi-drug resistance.

\section{Conflict of interests}

The authors did not declare any conflict of interest.

\section{ACKNOWLEDGEMENTS}

We thank the Fundação de Amparo à Ciência e Tecnologia do Estado de Pernambuco (FACEPE) for a $\mathrm{PhD}$ scholarship and Bryan Carruth for English language editing. 


\section{REFERENCES}

Albuquerque UP, Hanazaki N (2006). As pesquisas etnodirigidas na descoberta de novos fármacos de interesse médico e farmacêutico: fragilidades e pespectivas. Rev. Bras. Farmacogn. 16(Supl.):678689.

Albuquerque UP, Medeiros PM, Almeida ALS, Monteiro JM, Lins-Neto EMF, Melo JG, Santos JP (2007). Medicinal Plants of the Caatinga (semi-arid) Vegetation of NE Brazil: A Quantitative Approach. J. Ethnopharmacol. 114:325-354.

Almeida CFCBR, Cabral DLV, Almeida CCBR, Amorim ELC, Araújo JM, Albuquerque UP (2012). Comparative study of the antimicrobial activity of native and exotic plants from the Caatinga and Atlantic forest selected through an ethnobotanical survey. Pharm. Biol. 50(2):201-207.

Araújo RMS (2008). Purificação, Imobilização e Avaliação de propriedades biológicas da lectina da entrecasca de Crataeva tapia. Tese doutorado - Universidade Federal de Pernambuco - Centro de Ciências Biológicas.

Araújo TAS, Castro VTNA, Amorim ELC, Albuquerque UP (2012). Habitat influence on antioxidant activity and tannin concentrations of Spondias tuberosa. Pharm. Biol. 50(6):754-759.

Canales M, Hernández T, Caballero J, Vivar AR, Ávila G, Duran A, Lira $R$ (2005). Informant consensus factor and antibacterial activity of the medicinal plants used by the people of San Rafael Coxcatlán, Puebla, México. J. Ethnopharmacol. 97:429-439.

Caso M, Casciaro R, Pessano S, Ambrosini1 L, Manno G, Mentasti M, Morelli P, Minicucci1 L, Lorini R (2008). Lung exacerbation in a cystic fibrosis (CF) patient caused by a multi-resistant extended spectrum b-lactamase (ESBL) producing strain of Escherichia coli (EC). J. Cyst. Fibros. 7(S3):S24.

Coutinho HDM, Costa JG, Lima EO, Falcão-Silva VS, Siqueira-Júnior JP (2008). Enhancement of the antibiotic activity against a multiresistant Escherichia coli by Mentha arvensis L. and chlorpromazine. Chemotherapy 54:328-330.

Cowan MM (1999). Plant Products as Antimicrobial Agents. Clin. Microbiol. Rev. 12(4):564-582.

Ferreira Júnior WS, Ladio AH, Albuquerque UP (2011). Resilience and adaptation in the use of medicinal plants with suspected antiinflammatory activity in the Brazilian Northeast. J. Ethnopharmacol. 138:238-252.

Gobbo-Neto L, Lopes NP (2007). Plantas medicinais: fatores de influência no conteúdo de metabólitos secundários. Quimica Nova 30(2):374-381.

Gunics G, Farkas S, Motohashi N, Shah A, Harsukh G, Kawase M, Molnár J (2002). Interaction between 3,5-diacetyl-1,4dihydropyridines and ampicillin, and erythromycin on different $E$. coli strains. Int. J. Antimicrob. Agents 20:227-229.

Guyton AC, Hall JE (2006). Tratado de Fisiologia Médica. Elsevier Ltda. $11^{\mathrm{a}} \mathrm{Ed}: 434$.

Guzmán-Blanco M, Mejía C, Isturiz R, Alvarez C,Bavestrello L, Gotuzzoe E, Labarcaf J, Lunag CM, Rodríguez-Noriegah E, Salles MJC, Zuritaj J, Sease C (2009). Epidemiology of meticillin-resistant Staphylococcus aureus (MRSA) in Latin América. Int. J. Antimicrob. Agents 34:304-308.

Hemaiswarya S, Doble, M (2009). Synergistic interaction of eugenol with antibiotics against Gram negative bacteria. Phytomedicine 16:997-1005.

Javadpour MM, Juban MM, Lo WC, Bishop SM, Alberty JB, Cowell SM, Becker CL, McLaughlin ML (1996). De novo antimicrobial peptides with low mammalian cell toxicity. J. Med. Chem. 39:3107-3113.

Kerr KG, Snelling AM (2009). Pseudomonas aeruginosa: a formidable and ever-present adversary. J. Hosp. Infect. 73:338-344.

Leitão $F$, Leitão SG, Almeida MZ, Cantos J, Coelho T, Silva PEA (2013). Medicinal plants from open-air markets in the State of Rio de Janeiro, Brazil as a potential source of new antimycobacterial agents. J. Ethnopharmacol. 149:513-521.

Livermore DM (2007). Introduction: the challenge of multiresistance. Int. J. Antimicrob. Agents 29(Suppl. 3):S1-S7.

Livermore DM, Mushtaq S, James D, Potz N, Walker RA, Charlett A, Warburton F, Johnson AP, Warner M, Henwood CJ (2003). In vitro activity of piperacillin/tazobactam and other broad-spectrum antibiotics against bacteria from hospitalized patients in the British Isles. Int. J. Antimicrob. Agents 22:14-27.

Lorenzi H (1998). Árvores Brasileiras: Manual de identificação e cultivo de plantas arbóreas nativas do Brasil, Plantarum, Nova Odessa, SP.

Machado TB, Pinto AV, Pinto MCFR, Leal ICR, Silva MG, Amaral ACF, Kuster RM, Netto-dos Santos KR (2003). In vitro activity of Brazilian medicinal plants, naturally occurring naphthoquinones and their analogues, against methicillin-resistant Staphylococcus aureus. Int. J. Antimicrob. Agents 21:279-284.

Matias EFF, Santos KKA, Almeida TS, Costa JGM, Coutinho HDM (2011). Phytochemical screening and modulation of antibiotic activity by Ocimum gratissimum L. Biomed. Prev. Nutr. 1:57-60.

Matos FJA (1997). Introduction to experimental phytochemical. Editions UFC:Fortaleza.

Mbosso EJT, Ngouela S, Nguedia JCA, Beng VP, Rohmer M, Tsamo E (2010). In vitro antimicrobial activity of extracts and compounds of some selected medicinal plants from Cameroon. J. Ethnopharmacol. 128:476-481.

Morais-Braga MFB, Souza TM, Santos KKA, Guedes GMM, Andrade JC, Tintino SR, Costa JGM, Menezes IRA, Saraiva AÁF, Coutinho HDM (2013). Atividade antibacteriana, antifúngica e moduladora da atividade antimicrobiana de frações obtidas de Lygodium venustum SW. Boletín Latinoamericano y del Caribe de Plantas Medicinales y Aromáticas 12(1):38-43.

NCCLS - National Committee for Clinical Laboratory Standards (2008). Methods for dilution antimicrobial susceptibility tests for bacteria that grow aerobically: Approved standard. 6th ed. NCCLS document M7A6. National Committee for Clinical Laboratory Standards, Wayne, USA.

Pacheco R, Correia S, Monteiro R, Gonçalves A, Radhouani H, Ramos S, Carvalho E, Carvalho J, Igrejas G, Poeta P (2013). Multi-resistant extended-spectrum b-lactamase producing Escherichia coli in human urine samples in Portugal. J. Microbiol. Immunol. Infect. 46:399-404.

Palaniappan K, Holley RA (2010). Use of natural antimicrobials to increase antibiotic susceptibility of drug resistant bacteria. Int. J. Food Microbiol. 140:164-168.

Park YS, Lee H, Chin BS, Han SH, Hong SG, Hong SK, Kim HY, Ung $\mathrm{Y}$, Shin HB, Choo EJ, Han S-H, Song W, Jeong SH, Lee K, Kim JM (2011). Acquisition of extensive drug-resistant Pseudomonas aeruginosa among hospitalized patients: risk factors and resistance mechanisms to carbapenems. J. Hosp. Infect. 79:54-58.

Patil AG, Koli SP, Patil DA, Chandra N (2010). Pharmacognostical standardization and HPTLC fingerprint of crataeva tapia Linn. ssp. Odora (Jacob.) Almeida leaves. Int. J. Pharma BioSci. 1(2):1-14.

Razera F, Stefani S, Bonamigo RR, Olm GS, Dias CAG, Narvaez GA (2009). CA-MRSA em furunculose: relato de caso do sul do Brasil. Anais Brasileiros de Dermatologia 84(5):515-518.

Salvat A, Antonnacci L, Fortunato RH, Suarez EY, Godoy HM (2001). Screening of some plants from Northern Argentina for their antimicrobial activity. Lett. Appl. Microbiol. 32:293-297.

Samoilova Z, Smirnova G, Muzyka N, Oktyabrsky O (2013). Medicinal plant extracts variously modulate susceptibility of Escherichia coli to different antibiotics. Microbiol. Res. 169(4):307-313.

Wagner H, Ulrich-Merzenich G (2009). Synergy research: Approaching a new generation of phytopharmaceuticals. Phytomedicine 16:97110.

Wright ED, Perinpanayagam RM (1987). Multiresistant invasive Escherichia coli infection in south London. Lancet 329(8532)556557.

Xie Q, Johnson BR, Wenckus CS, Fayad MI, Wu CD (2012). Efficacy of Berberine, an antimicrobial plant alkaloid, as an endodontic irrigant against a mixed-culture biofilm in an in vitro tooth model. Basic Res. Technol. 38(8)1114-1117.

Xing M, Shen F, Liu L, Chen Z, Guo N, Wang X, Wang W, Zhang K, Wu X, Wang X, Li Y, Sun S, Yu L (2012). Antimicrobial efficacy of the alkaloid harmaline alone and in combination with chlorhexidine digluconate against clinical isolates of Staphylococcus aureus grown in planktonic and biofilm cultures. Lett. Appl. Microbiol. 54:475-482.

Yap PSX, Lim SHE, Hu CP, Yiap BC, (2013). Combination of essential oils and antibiotics reduce antibiotic resistance in plasmid-conferred multidrug resistant bacteria. Phytomedicine 20:710-713. 